\title{
THE CHANGING NATURE OF TURKISH-SYRIAN RELATIONS: A GLOBALIZATION PERSPECTIVE
}

\author{
MURAT GÜNEYLİOĞLU* \\ Dokuz Eylül University
}

\begin{abstract}
This paper examines globalization's effects on the change in Turkish foreign policy towards Syria in a comparative perspective. Through the 1990s Turkish foreign policy towards Syria was shaped by realist parameters as Turkey relied on an alliance with Israel, and hard power seeking deterrence and coercion. However after Syria submitted to Turkey's demands and signed a counter-terrorism accord in 1998, the two states engaged in a certain rapprochement process. Most notably, following the Iraq war that promoted common threat perceptions, Turkey put a new face into practice in its foreign policy. In the 2000s, besides its growing military capabilities, Ankara also drew on soft power in its new approach to Syria and introduced many new opportunities for its neighbor through the bilateral cooperation. That carried Turkey's relationship with Syria to unprecedented levels of collaboration in the political, economic and social realms. As elaborated in the study, the changes in Turkey's new approach towards Syria resonate with some significant theoretical perspectives in the literature on globalization and foreign policy change. In this respect, Turkey's new foreign policy approach is suggested as a late response to globalization's challenge to traditional foreign policy formation as the regional security dynamics in the 1990s impeded a rapprochement. Along with the changes in Turkish foreign policy towards Syria in the first decade of the 2000s, the regional implications of Ankara's new approach are also discussed. Lastly, the limits of Turkey's new foreign policy approach are examined touching upon the developments in Syria since the "Arab Spring."
\end{abstract}

Key words: Turkish foreign policy, Syria, globalization, structural power, soft power.

\section{TÜRKIYYE-SURIYE ILISTKILLRININ DEĞISSEN DOĞASI: BIR KÜRESELLESME PERSPEKTIFI}

\section{$\ddot{O Z E T}$}

Bu çalışmada, küreselleşme sürecinin Türkiye’nin Suriye’ye yönelik dış politikasında görülen değişim üzerindeki etkileri, karşılaştırmalı bir perspektifte incelenmektedir. 1990'lar boyunca Suriye'ye yönelik Türk dış politikası realist parametreler tarafından biçimlendirilmiş, Türkiye İsrail ile kurduğu ittifakla beraber caydırma ve zorlamayı amaçlayan sert güce dayalı bir politika izlemistir. Ancak 1998 yılında Suriye'nin Türk tarafinın taleplerini kabul ederek terörle mücadelede işbirliğ i anlaşması imzalamasının ardından iki ülke belirgin bir yakınlaşma süreci içine girmiştir. Ortak tehdit

* Murat Güneylioğlu is an instructor in the Department of International Relations at Kırklareli University, Kavaklı, Kırklareli, Turkey. E-mail: guneylioglumurat@yahoo.com 
algılamalarına yön veren Irak savaşının ardından ise, Türkiye daha açık bir şekilde yeni bir tür dış politika izlemeye başlamıştır. 2000'lerde Ankara, Suriye’ye yönelik yaklaşımında askeri gücünün yanı sıra yumuşak güç unsurlarına da dayanmış ve karşılıklı işbirliği vasıtasıyla komşusuna birçok yeni firsat sunmuştur. Türkiye'nin bu tutumu Suriye ile olan ilişkilerini siyasi, ekonomik ve sosyal alanlarda daha önce benzeri görülmemiş bir işbirliği düzeyine taşımıştır. Çalışmada incelendiği üzere, Türkiye'nin yeni Suriye yaklaşımında görü̈len değişiklikler, küreselleşme ve dış politika de ğişimi konusunda literatürde yer alan bazı önemli teorik perspektiflerle uyum göstermektedir. Bu bă̆lamda Türkiye’nin yeni dış politika yaklaşımı, küreselleşme sürecinin geleneksel dış politika yapım süreci üzerinde ortaya koyduğu dönüştürücü etkilere geç kalmış bir cevap olarak nitelendirilmektedir. Bu geç kalmanın başlıca sebebi ise 1990'lardaki bölgesel güvenlik dinamiklerinin böyle bir yakınlaşmayı engellemesi olmuştur. 2000’lerin ilk on yılında Türkiye'nin Suriye politikasında görülen de ğişikliklerle beraber, Ankara’nın yeni yaklaşımının bölge politikaları üzerinde ortaya koyduğu anlamlar da çalışma içinde tartışılmaktadır. Son olarak, Türkiye’nin yeni dış politika yaklaşımının sınırları, “Arap Baharı'ndan” bu yana Suriye'de yaşanan gelişmelere değinerek incelenmektedir.

Anahtar kelimeler: Türk dış politikası, Suriye, küreselleşme, yapısal güç, yumuşak güç.

The Turkish foreign policy change towards Syria in the last several years has been a subject drawing considerable scholarly attention. Having come to the edge of a military conflict in 1998 due to Syrian support of the PKK, the two states managed to transform their bilateral relationship into good neighborliness and a strategic partnership that sought economic integration within little more than a decade. Scholars writing on the changing nature of Turkish-Syrian relations have proposed reasons such as the changing domestic leadership in both countries, high-level governmental visits (Özer, 2007), the shifts in regional and global security dynamics (Altunışık and Tür, 2006; Tür, 2010) and the Europeanization of Turkish foreign policy (Aras and Polat, 2008). However; none of them has concentrated on the challenges brought by the globalization process in contrast to the traditional foreign policy formation in an effort to analyze the structural changes in the new global-international environment inside of which this foreign policy change has occurred. This paper analyzes the Turkish foreign policy change towards Syria in a comparative perspective by emphasizing new trends, tendencies and methods of foreign policy making in the face of globalization. It deals with the question of how the profound changes in foreign policy understanding triggered by the globalization process are absorbed within Turkey's new approach towards Syria in particular and towards the Middle East in general.

The first section deals with the theoretical propositions on globalization's challenge to traditional foreign policy understanding and its transformation. The second one proposes a historical context in which to examine the main foreign policy issues with Syria. The following section analyzes Turkish foreign policy towards Syria in the 1990s period during which Turkey embraced a conventional realist foreign policy approach. After examining the conditions that provided the possibility for foreign policy change in the third section, the paper then examines Turkey's changing approach towards Syria in a globalization perspective. Lastly, the limits of Turkey's new approach are discussed. 


\section{THEORETICAL FRAMEWORK: GLOBALIZATION AND FOREIGN POLICY (ANALYSIS)}

Foreign policy can be defined simply as an "area of politics which is directed at the external environment [i.e. beyond the state's borders] with the objective of influencing that environment and the behavior of other actors within it, in order to pursue interests, values and goals" (Keukeleire and MacNaughtan, 2008). Foreign policy analysis (FPA), on the other hand, is a distinctive branch of international relations that examines how international actors (primarily state governments and leaders) make choices in shaping and implementing their foreign policies (Garrison et al., 2003: 163). The mainstream foreign policy analysts have always focused primarily on the state, underlining its role in safeguarding the common interest of those living within its boundaries. In this respect, foreign policy is viewed as a separate area of government that ensures the security, defends the fundamental values of the state and seeks to further the domestic well-being of the society (Chong, 2007: 7). Yet, through the 1970s, an alternative pluralist framework developed which emphasized the roles of a wider range of actors other than states, such as the NGOs, multinational corporations (MNCs) and international institutions that operate in relations of interdependency. For pluralists, thus, foreign policy as a site of governmental/bureaucratic action becomes less important than the external relations of those multiple actors (Groom, 2007: 199).

In the coming years, globalization, defined as the "widening, deepening and speeding up of global interconnectedness" (Held et al., 2003: 67), introduced new challenges to the concept of foreign policy. Some scholars even argued that globalization has rendered foreign policy redundant (see Hill, 2003a: 13). As Hill pointed out, there was a simultaneous decline in interest in FPA. The first reason for that was the growth of skepticism about the autonomy of the state and the second one was the argument that 'foreign' is no longer a meaningful category since globalization has come to eliminate the distinction between internal and external spheres through the transnational actions of the new actors (Hill, 2003b: 235). Yet, Hill argued that we are far from the point of the demise of the state nor we are welcoming the erased boundaries because both the legal and the socio-cultural framework that differentiate the internal and the external realms continue to exist. Furthermore, transnational actors like the MNCs are not capable of exercising political responsibilities and often turn to their governments to influence their strategies regarding the states' function in securing their own interest (Hill, 2003b: 236). States, in this new environment, continue to play significant roles in spanning boundaries rather than acting as gatekeepers for the defense of the country as the conventional view suggested (Groom, 2007: 212).

For all these reasons above, foreign policy is likely to maintain its significant role in the global era, but in a transformed manner (Chong, 2007; Garrison et al., 2003; Groom, 2007; Keukeleire and MacNaughtan, 2008). Globalization is, in fact, a process that promotes winners and losers in material terms and this fact forces the states to look out for their interests in the external realm which is getting more complicated. In this respect, the changes in the structure of the global world can be better understood through the 'global governance' perspective that emphasizes the emerging "complex formal and informal institutions, mechanisms, relationships and processes between and among states, markets, citizens and organizations, both inter- and non-governmental, through which collective interests on the global plane are articulated, rights and obligations are established, and differences are mediated" (Aras and Crowther, 2009: 10). According to this perspective, states should concern themselves principally with influencing those structures, mechanisms or processes in order to gain a substantial position. 
Therefore, in the global age, states should rely on something more than the military capabilities and relational power in order to exert influence on the external space. At this point, some scholars take the concept of 'structural power' instrumentally in explaining the new trends in foreign policy making in the global world (see Chong, 2007: 66-69; Holden, 2009; Keukeleire 2002; Keukeleire and MacNaughtan, 2008). In her commonly-cited study on this analytical concept, Strange defines structural power as "the power to shape and determine the structures of the global political economy within which other states, their political institutions, their economic enterprises and (not least) their scientists and other professional people have to operate" (1994: 24-25). Structural power takes its most explicit form when an influential actor designs international regimes of rules and customs that are assumed to govern international economic relations. Yet, as Strange points out, this is only one aspect of structural power for the concept has a broader meaning. In general, it is "the power to decide how things shall be done, the power to shape frameworks within which states relate to each other, relate to people, or relate to corporate enterprises" (Strange, 1994: 25). In this respect, the possessor of structural power is able to change the range of choices open to others by imposing some international legal constraints or through the attractiveness of specific principles in conducting international relations. "The range of options available for an entity could be extended through the development of new opportunities, or restricted through the imposition of costs or risks, rendering some choices more attractive, and others more difficult" (Keukeleire and MacNaughtan, 2008: 24). In short, structural power focuses on setting the organizing principles and rules for the economy-related and political games being played among international actors (nation states, non-state entities, entrepreneurs etc.). Through altering the context in which actors operate, structural power can lead to fundamental and long-lasting effects in the external realm, an arena that gets further complicated by globalization.

Drawing on Strange's concept of structural power, Keukeleire and MacNaughtan (2008) then developed the idea of structural foreign policy that may be a significant tool in order to understand the changes that Turkish foreign policy is going through in the face of globalization (see also Keukeleire, 2002: 12-14). Following the Westphalian order of the European states and the Cold War period in the 20th century that featured competition in power politics and bipolar divisions, Keukeleire and MacNaughtan (2008) emphasize the need for reformulation of foreign policy to respond to the challenges of the new world order. As we all observed, the demise of the bipolar international system soon led to instability in the former communist bloc and the Third World. In the transition period, those regions became characterized by the emergence of regional or intra-state conflicts among different ethnic, political and religious groups. According to Keukeleire and MacNaughtan (2008), the rising threats, risks and challenges from those areas were in fact rooted in the resolution of long-standing structures beyond the Western bloc. As the nature of the conflicts and threats changed, the need to create more stable and sustainable structures in those regions moved up in the agenda. That required both new types of military capability and a wider range of non-military instruments. For those authors, the crises in Bosnia, Kosovo, Afghanistan and Iraq all demonstrated that wielding military force alone would not bring lasting peace and long-term stability. Thus it became clear that foreign policy needed to focus more on structures. In this respect, structural foreign policy refers to an approach "which, conducted over the long-term, seeks to influence or shape sustainable political, legal, socio-economic, security and mental structures" that characterize "not only states and interstate relations, but also societies, the position of individuals, relations between states and societies, and the international system as a whole" (Keukeleire and MacNaughtan, 2008: 25-26). 
The idea of structural foreign policy examined by Keukeleire and MacNaughtan (2008) emphasizes some neglected (but significant) aspects of foreign policy in the traditional approach and covers many of them together. In this sense, structural foreign policy differs from the conventional one in its approach to the core concepts of FPA (Keukeleire and MacNaughtan, 2008: 19-25). First of all, the former deals with a wide range of actors such as societies, business chambers, multinationals, international organizations, NGOs; and some other governmental actors apart from foreign and defense ministries (like ministries of finance and the interior) because, in order to manage changes in many levels of foreign relations including the political, economic and social realms, multiple governmental and non-state actors should be involved in the process. Secondly, in terms of interests and objectives, instead of formulating a narrow definition of national interest, structural foreign policy regards promoting the basic interests of other states and non-state actors. Since the global context of the 21 st century increases mutual dependence and vulnerability, to regard the collective and the other's interests reflects a healthy choice for securing far-sighted self interest. Thirdly, a structural foreign policy defines security in a broader sense that goes beyond a national-territorial security concept and deals with threats arising from the global, societal and individual levels. On the other hand, in regard to a bilateral relationship between particular states, structural foreign policy calls for a desecuritization of the main issues in the conflict. This means a process in which security problems are gradually removed from the security agenda and placed on the political agenda that deals with everyday issues. Thus, desecuritization would bring more mutual confidence through which a ground for comprehensive dialogue can be established that would provide structural changes for establishing cooperative relationships. This prospect has been applied in the case under investigation here, namely the desecuritization of the Hatay and the water problems.

Fourthly, structural foreign policy embraces the argument that, though being essential in the global age, military and diplomatic powers/instruments remain insufficient if they are not complemented by economic and financial powers/instruments. Accordingly, hard power must be complemented by soft power. Contrary to hard power that is based on coercion, soft power reflects the ability to influence others' behaviors through attraction. It is mostly based on the attractiveness of an entity's culture, values, political ideals and policies. Soft power is enhanced when these are seen to be legitimate (Nye, 2004: 256). ${ }^{(1)}$ Structural changes are often manipulated by the combination of hard and soft power, i.e. carrots and sticks together. Last, but not the least, conventional and structural foreign policies differ in their foci. While the former seems to be actor-, conflict- and event-oriented, the latter is rather process-, structure- and context-oriented (Keukeleire and MacNaughtan, 2008: 24). In other words, while traditional foreign policy focuses on managing other actors and conflicts in terms of a particular interest, structural approach looks for the reasons of the conflicts in the deeper political, economic, cultural structures and tries to reshape them in order to manage the threats and increase the opportunities. However it is important to note that Keukeleire and MacNaughtan (2008) suggest that conventional and structural foreign policies are not contradictory but are rather mutually complementary. The authors give the historical progress in the Balkans as an example, emphasizing that a structural approach has been possible only after there were successful conventional foreign policy actions that brought stability through military operations and diplomatic initiatives. On the other hand, the authors argue that the enduring stability could only be guaranteed through the creation of a comprehensive set of new structures (Keukeleire and MacNaughtan, 2008: 26-27). In our case too, a new approach towards Syria was developed after a military threat that compelled Damascus to give up supporting the PKK. At this point, a successful structural approach does not ignore hard security issues; it always needs to focus comprehensively on various relevant structures (e.g. political, 
legal, social, economic and security structures) together (Keukeleire and MacNaughtan, 2010: 5). Ignoring one of these aspects may result in its failure.

Before concluding this section, Nimet Beriker-Atiyas's (2001) study that exposes the needs for change in foreign policy understanding of Turkey in the post-Cold War context has to be elaborated here, as the model she proposed is of significance in her focus specifically on Turkey's conditions. BerikerAtiyas's (2001) article "The New World, Old Approaches" criticizes Turkish foreign policy which clearly reflects the realist pattern of behavior. For her, this policy contrasts with the new dynamics of the increasingly globalized world after the end of bipolarity. The author defines Turkish foreign policy as re-active and defensive in nature, affected mostly by balance of power considerations that have called for reliance on military and economic power. Through the 1990s, Turkish foreign policy was limited to the aim of defending the state's constant stances against the problematical cases using classic diplomatic tools. Turkish governments embraced the idea that states are passive units affected by the events within the international environment. In this sense foreign policy was totally equated with national defense policy. Instead of this kind of an 'old approach' reminiscent of the Cold War period, Beriker-Atiyas proposes another pro-active type of foreign policy that actively seeks reshaping the political, economic, social procedures/environments in the periphery of Turkey as these regions are going through a transformation that boosts transnational interdependency and global interconnectedness. Beriker-Atiyas suggests that in the 21st century Turkey should define its national interests according to the shifting international conditions rather than in a static sense oriented in response to specific threats. Accordingly Turkey should contribute to the peaceful resolution of regional problems and try to enforce the principles of co-existence regarding common benefits in its neighborhood in order to secure its wider national interest (Beriker-Atiyas, 2001: 53). BerikerAtiyas (2001) also suggests that the instruments for managing these tasks are soft power, preventive and complementary diplomacy and mediation activities. For the author, the state is not the only actor in serving these foreign policy objectives; rather it should cooperate with other politically and economically salient actors to create a synergy.

All these theoretical perspectives examined above have the common emphasis that foreign policy should go beyond the limitations of the realist logic and the state-centric view of international relations and instead deal with the new political, economic and social processes in global dynamism in which multiple actors operate. Yet this does not mean that those theoretical views are constructed in contrast to the main assumptions in the realist theory of international relations. The authors' emphasis on soft and structural power also does not imply that hard power is an obsolete instrument in dealing with international crises. As explicitly suggested in the study on structural foreign policy, the security dimension is essential to build the ground for structural change and sometimes can be managed only through the conventional foreign policy utilizing hard power (Keukeleire and MacNaughtan, 2008: 26-27, see also Keukeleire, 2002: 21-22). Turning to our case, in 2011 Turkish-Syrian relations again started to be dominated by security issues due to the Assad government's armed suppression of civil protests that emerged as repercussions of the "Arab Spring."(2) Today, the necessary international consensus for military measurements regarding the Syrian crisis has not entirely come about. However, the possibility of a multilateral military operation under the UN mandate or through the NATO alliance pushes Turkey to undertake serious commitments in managing the process as a neighbor state and active player in regional politics. In this respect, even if the military option would be laid aside, Turkey may engage in certain coercive methods such as economic sanctions, arms embargo or a campaign of political isolation as some other ways to exercise hard power. These observations, along with the 
experiences in the case of Libya, prove that the conventional methods and hard power instruments are not yet exhausted in the new world order.

Through the theoretical perspectives represented above, this paper now will examine the Turkish foreign policy change towards Syria in the last years. The changes in relations are suggested as a late response to the challenges of globalization to conventional foreign policy understanding. Turkey's inability to respond earlier, on the other hand, resulted from the existence of some unresolved hard security problems and regional dynamics which impeded a rapprochement between the two states in the global era. In order to build a comparative perspective, those problems and dynamics have to be underlined first.

\section{HISTORICAL CONTEXT: THE WEIGHT OF CHRONIC PROBLEMS AND BIPOLAR RIVALRY}

Turks and Syrians share a long history as they lived together for almost four centuries under the Ottoman Empire. But this common history did not result in close partnership after the Turkish Republic and Syria were born. Both Arab nationalists and Turks conceptualized their identity as otherness. For the Arab nationalists, the Ottoman period was defined as the first part of double colonialism which denied their own national and economic development. On the other hand, the Turkish Republic's new state elite associated the Arab narrative with 'deep-rooted suspicion' and 'betrayal,' pointing to the Arab community's collaboration with Western powers in the disintegration process of the Empire (Jung, 2005). After 1923, the Turkish Republic, with a clear Western orientation, followed a noninterventionist and hands-off approach to the Middle East which it saw as a backward zone of conflict. One exception became the incorporation of Hatay (Alexandretta) in 1939, when Syria was forced by France to give the province to Turkey. Syria never accepted the legitimacy of this unification and regarded it as another manifestation of Turkish colonialism that aimed to divide the "historical Syria" (Altunışık, 2010: 151). Even today, the Hatay issue is alive in Syrian popular culture, and the province is shown as a part of the country in the official maps.

During the Cold War, Turkey and Syria allied themselves with rival blocs. After joining NATO, Turkey harmonized its policy with the Alliance and sought to incorporate the regional states into the Western defense system against the increasing influence of the Soviet Union. However, this was done at the expense of relations with those states (Bozdağlığlu, 2003: 115). Turkey embraced the Western oriented, democratic Israel as a natural ally in the region. But the Arab states such as Egypt and Syria maneuvered towards the Soviet Union in order to provide support in their struggle against Israel's influence in the Middle East. In 1955 when Turkey introduced the Baghdad Pact that included Great Britain, Turkey, Iraq, Iran and Pakistan as members, Egypt and Syria perceived it as "a new instrument of Western imperialism, which was designed to recolonize the Arab world" (Bozdağlığlu, 2003: 119). In a counter move, Syria appealed to Egypt and signed a military agreement with it for a unified command in October, 1955. Consequently, Turkey was forced to enter into a secret alliance with Israel, namely the Phantom Pact in the same year to balance the threat on its borders (Walker, 2006: 71). The cold war rivalry, thus, drew Turkey and Syria into a hostility that was enforced by political, ideological and identity differences.

Another issue which is known as the water dispute has also been a determining factor in the problematic relations. In the 1970s and 1980s, Turkey began to build a series of dams and irrigation systems with 
the South Anatolia Project (GAP) on the Euphrates River which rises in Turkey and flows through Syria and Iraq. Damascus protested Turkey's controlling of the Euphrates' water claiming that it would decrease the amount and the quality of water flowing towards Syria. In countering the GAP project, Syria allied with Iraq, the other country in the river's basin, and also took the issue to the agenda of the Arab League meetings in order to turn the water problem into a Pan-Arab issue. Throughout the 1980s and 1990s, besides the other problems, Syria provided sanctuary to the PKK, the ASALA (Armenian Secret Army for the Liberation of Armenia) and the Turkish radical left (Dev-Sol). The Turkish side often coupled it to the water problem (Altunışık and Tür, 2006; Pamukçu, 2004). This view was symbolized in a statement by the former Foreign Minister Deniz Baykal in 1995 who suggested "Syria as a neighbor country should stop being the headquarters of a terrorist organization. It can be thought that hands with the blood of terror could be washed with more 'water.' However, Turkey will never bargain the use of terror for water" (Baykal, in Tür, 2010: 164). After the 1980 military coup in Turkey, the leaders of the PKK escaped to Syria. The PKK militants found shelter in Syria and the Syrian dominated Bekaa Valley in Lebanon, while the PKK's head, Abdullah Öcalan, used Damascus as his base. That situation promoted the most immediate threat to Turkey's security in the 1990s.

In fact, in the late 1980s and early 1990s there was a major change in the type of foreign policy understanding in Turkey under the leadership of the President Turgut Özal. Drawing on an understanding of the new international conjuncture shaped by globalization, Özal tried to reformulate the economic policy of Turkey and, accordingly, the foreign policy. As the Turkish economy was transformed into an export-oriented model within the liberalization process, Turkey encouraged its businessmen and entrepreneurs to seek foreign trade relations and investments. Turgut Özal viewed non-governmental actors (business chambers, NGOs, ethnic, religious groups etc.) as significant actors in foreign policy in order to improve partnerships with other states and societies (Laçiner, 2009). In the Özal period international trade was boosted especially between the former socialist world and Turkey, as the latter played an active role in integrating the region into the global economic system. Ankara further tried to restructure political, economic, social and cultural environments in the Central Asian Turkic World through the projects of the TIKA (Turkish International Cooperation and Development Agency) and sought some kind of economic and political union with those states (Aydin, 2003). However, as Kirişci, Tocci and Walker (2010: 20) suggest, the new pattern of foreign policy did not manage to expand vis-à-vis the Middle East because Arab leaders remained lukewarm to the Özal leadership approach, in spite of the latter's intentions to develop closer relations with the region as well. The authors specify the reasons as trade sanctions on Iraq, souring relations with Egypt and the growing terrorism in southeast Anatolia that was supported mainly by Syria. In order to resolve the bilateral problems, Ankara signed a security protocol with Syria in 1987 that called for obstructing "groups engaged in destructive activities directed against one another on their own territory" and promised to ensure a specific amount of water from the Euphrates (James and Özdamar, 2009). Nevertheless, it did not bring a solution to the problem as Syria denied that Öcalan was in Damascus and continued to support the PKK. Therefore the ongoing instability in the Middle East and the terrorism problem became the main issues shaping the relationship between Turkey and Syria through the 1990s.

\section{TURKEY AND SYRIA IN THE 1990’S}

The end of the Cold War resulted in the emergence of many uncertainties with raising inter-state and ethnic conflicts in the periphery of Turkey. Contrary to the prospects of globalization in a foreign policy change, Ankara primarily had to deal with security problems in the traditional sense. Although 
Turkey and Syria were together in supporting the international coalition forces against Saddam's Iraq in the First Gulf War, a fact that reflects the pragmatic move of Damascus in the new conjuncture, this ad-hoc alignment did not bring a rapprochement in the realm of security. The vacuum of authority in Northern Iraq after the war only increased the PKK's logistical advantages, while the terrorist organization gained considerable political-financial support from Turkey's neighbors that Ankara had problems with, such as Syria and Iran.

Besides continuing to support the PKK, Syria also appealed to external balancing acts against Turkey in the 1990s. The Hafez al-Assad regime turned to new allies, namely to Armenia and Greece and concluded a military partnership with the latter in 1995 that permitted the Greek air force to land at Syrian air bases. On the other hand, Moscow, having hosted the third meeting of the "Kurdish Parliament in Exile," also signed a military and technical cooperation agreement with Greece in the same year, and approached Iran with a plan to build a strategic partnership. (Aykan, 1999). The developments in Turkey's new environment pushed Ankara to perceive that it had been surrounded by hostile alignments. Most strikingly, Şükrü Elekdağ, former Turkish ambassador to Washington, suggested that in 1996 Turkey's defense strategy must be prepared for "two and a half wars," indicating the full scale war potential against Syria and Greece and the reduced-scale military struggle against the PKK insurgency (Elekdağ, in Kösebalaban, 2010: 45). Under these conditions, Turkish foreign policy was formulated on the realist pattern of behavior. Specifically, Turkey turned to Israel, an available partner in 1996, to balance the external threats in its vicinity in keeping with the classical neorealist theory on a balance-of-threat alliance formation (Walt, 1987). ${ }^{(3)}$ In February 1996, Turkey and Israel concluded the "Military Training and Cooperation Agreement" with provisions for "the exchange of military information and joint military training, including naval access to the ports of both countries and Israeli air force training flights from Turkish bases over Turkish territory" (Martin, 2004: 182). Although the Turkish side pointed out that the military cooperation was not directed at the third parties, some official statements suggested the existence of expectations concerning "the deterrence of Syria from supporting the PKK and the Arab countries from supporting Syria" (Aykan, 1999: 176). Syrian Vice President, Khaddam, on the other side, described the military partnership as "the greatest threat to the Arabs since 1948," referring to the establishment of the State of Israel (Khaddam, in Bengio and Özcan, 2000: 3).

As Aykan (1999) suggests, in the 1990s, Syrian support for the PKK was far stronger than other foreign governments, as the state hosted its headquarters and training camps, helped recruit personnel and exerted influence on the PKK strategy and tactics. Following the 1987 protocol that had failed to generate the expected results, Turkey also signed agreements with Damascus regarding cooperation against terrorism in 1992 and 1993. However those agreements, likewise, did not terminate the PKK's activities in Syria (James and Özdamar, 2009). In 1996, Turkey suspended all official contacts with Syria, and touched upon Article 51 of the UN Charter citing Turkey's right to military self-defense against this de-facto aggression. In October 1998 Turkey further threatened the use of force against Syrian support for the PKK and deployed 10,000 troops on its Syrian border. This intimidation with 'hard power' tactics finally forced Damascus to submit to the Turkish demands. The Syrian President, Hafez al-Assad, sent word to Ankara that the government had already begun arresting the PKK militants and would expel them along with Öcalan from Syria. The crisis ended when the Turkish side confirmed that Öcalan had been expelled from Syria. Then on October 20, 1998 the Adana Accord on the cooperation in counter-terrorism was signed between Ankara and Damascus (Sezgin, 2002: 4950). Ultimately this agreement produced a Syrian compliance with all of Turkey's demands, while the 
latter gave nothing in return. This development opened the way for the desecuritization of the water and Hatay issues, as Syria gave up using the terrorism card against Turkey.

In sum, during the 1990s, Turkish foreign policy towards Syria was shaped by the realist principles. As Beriker-Atiyas (2001) suggests, Turkey appealed to hard power and alliance politics regarding the balance of power to deal with its problems with Syria. It handled itself reactively against the developments in its neighborhood and therefore could not concentrate on reshaping the political, economic and social processes in the region. Yet, Ankara's foreign policy implementation in the first decade after the Cold War was not in stark contrast to the foreign policy behavior of other regional and great powers. In this transition period with rising threats and conflicts, bringing stability in the Balkans and Caucasus became possible only through the conventional foreign policy that used diplomacy and military power. In the Balkans, the role of multilateral peacekeeping forces and the diplomatic efforts by the US and its partners were crucial. On the other hand, reconstruction in the Caucasus through the international projects waited until 1994 when the ethnic conflicts were frozen by the Russian protectorate. Accordingly, in the Middle East the situation was also troubled and complicated in the aftermath of the First Gulf War. The US dual containment policy over Iraq and Iran and the system of counter alliances among regional states (e.g. Arabs vs. Israel, Turkey vs. Syria and Iran), prevented the Western states and regional actors from using structural and soft power instruments. In this context, the agenda of Turkey-Syria relations was dominated by hard security issues. It was not likely that Turkey would establish economic and social ties of cooperation with Damascus in that period when even diplomatic contacts reached a deadlock. Therefore, an urgent solution to the security problem with Syria through hard power emerged as a rational approach, considering the weaker position of Damascus against Turkey in terms of military capabilities that cut Syria's options when facing the military threat. ${ }^{(4)}$ For all these reasons above, the change in the Turkish approach to Syria in line with a globalization perspective waited for the resolution of the terrorism problem through a conventional approach and for other revisions in Middle Eastern affairs.

\section{THE AFTERMATH OF 1998 CRISIS: CHANGING REGIONAL DYNAMICS}

The cessation of Syrian support to PKK terrorism provided a rapprochement between Ankara and Damascus in the security realm. Towards the 2000s, as provided for in the framework of Adana agreement, regular meetings were held by the Joint Security Committee comprised of military officials from both sides (Altunışık and Tür, 2006: 238). In June 2000, the Turkish President Sezer's attendance at Hafiz al-Assad's funeral ceremony was also seen by some scholars as a historic step towards ameliorating the relations (Ar1 and Prinççi, 2010; Özer, 2007). In the face of the Iraq war, this rapprochement process gained some other dimensions. The Turkish Parliament's rejection on March 1, 2003 of support for the US war efforts in Iraq brought Turkey and Syria closer together, as the latter also chose to stand against the US operation. At a meeting in Istanbul in 2003 organized by Turkey, Syria attended along with Iraq's other neighbors, from which came a declaration exposing their common aim at heading off the US led operation (Fuller, 2008: 71). Additionally, the Second Gulf War increased the perception of a threat common to Turkey and Syria related to the future of Iraq and the increasing Kurdish autonomy in the North. In 2004, terrorist activities in the southeast of Turkey again escalated. At the same time, Syria was also worried about the repercussions of the developments in Iraq on its own Kurdish population (roughly 1.7 million, 9\% of the total Syrians). As Altunış1k and Tür suggest, riots in March 2005 in the Kurdish-populated areas of Syria reinforced such anxieties (2006: 241). Therefore Syria backed Turkey's announcements that Ankara was against the 
establishment of a Kurdish state, with Syrian President Bashar Assad emphasizing that "a Kurdish state would violate our red line too" (Altunış1k and Tür, 2006: 241). In the early 2000s anti-Americanism in Turkish public opinion was growing, while Ankara was disappointed with Washington's and Israel's increasing ties to Kurdish actors in Iraq. These developments led to a political and societal consensus to strengthen Turkey's ties to the regional states and its neighbors (see Altunışık and Tür, 2006: 239244).

In the 2000s, the Bush government's unilateral strategy based on military power created a vacuum for soft power projections in the Middle East since Washington did not manage to transform the region into a liberal, peaceful zone but, rather, further complicated the situation. As a result, the development in relations between Turkey and Syria created the opportunity for the former to utilize 'soft power,' in contributing to Syria's economic and political transformation. After 9/11, Syria was on the US list of the states sponsoring terrorism. Washington put great pressure on Damascus for providing an international isolation in order to change the Syrian regional strategy. The aim was to sever the ties between Syria and the Iraqi radical groups as well as Syria's relations with Hezbollah in Lebanon. To achieve this, even a change in Syria's regime through a military operation appeared to be an option for the US (Orhan, 2009). The Western world and the traditional allies of Syria like Russia and France supported this international campaign of isolation. However Turkey took a different stance. In December 2004, when the international campaign that aimed at forcing Syria to withdraw its military presence from Lebanon was in its peak, the Turkish Prime Minister Recep Tayyip Erdoğan, visited Damascus (Ayhan, 2009). Furthermore, the Turkish President Ahmet Necdet Sezer visited Syria in February 2005 following the assassination of the former Lebanese Prime Minister Rafiq Hariri for which Syria was charged. Sezer's visit to Damascus took place against all the warnings and protests by the US that called for Turkey's abiding by the decisions of the international community on sanctions against Syria. ${ }^{(5)}$ During these visits and with other diplomatic communications, Turkish officials emphasized Damascus's "need for domestic reform, for the withdrawal of Syrian forces from Lebanon (which took place) and for the need to ensure that international jihadists do not enter Iraq from Syrian territory" (Fuller, 2008: 73). This attitude of Turkey and the constructive dialogue between the two were crucial as Syria looked for relations with the regional states to break the international isolation. Talking about this period, Syrian Deputy Foreign Minister Ammura suggested that "Syrians would not forget Turkish support given in rough times" (Ammura, in Arı and Prinççi, 2010: 9).

It is also interesting to note, as Altunış1k and Tür suggest, during the 1990s it was Turkey that advocated pressuring Syria, and therefore criticized the Clinton administration for being too accommodating towards Damascus. However after solving the PKK problem with Syria, Turkey turned to a constructive-engagement approach, while the Bush administration adopted a tougher stance towards the country (Altunışık and Tür, 2006: 243). In this period, Turkey served for Syria as a door to Europe for economic and trade relations, while Turkey's policy impeded radicalization of Damascus's strategies and its maneuvering towards Iran (Ayhan, 2009: 31). In the new regional conditions, therefore, Turkey's attractiveness increased greatly in the perspective of the Syrian regime. That consequently fed Ankara's soft power capacity regarding the relations with Syria, and set the opportunity for building more cooperative bilateral relations between the two states.

In sum, after the Iraq war the distribution of regional threats by and large changed and that removed most of the motivations for Turkey and Syria to engage in counter-balancing actions against each other ${ }^{(6)}$ In the new conjuncture, against the US pressure on Turkey regarding its relations with the 
Syrian regime, Ankara sought a more independent role and pursued its own developing interests in its neighborhood. Turkey also tried to harmonize its national objectives with the global processes and aimed for Syria's integration into the world economic system. After setting the ground for cooperation in the security realm using classical diplomatic tools, the next step would be carrying the cooperation to economic-social spheres to enforce a sustainable partnership between the two countries.

\section{TURKEY'S NEW FOREIGN POLICY APPROACH TOWARDS SYRIA} $(2004-2010)^{(7)}$

As an international relations academician and the current Foreign Minister of Turkey, Ahmet Davutoğlu's study (2001) on the Strategic Depth doctrine represents his understanding of the need for a revision of Turkey's foreign policy in the globalization era. Therefore, some quotation from his book, one that is highly influential in the Justice and Development Party (AKP) Government's foreign policy, seems to be necessary here. After the end of the Cold War, Davutoğlu suggested that the dynamism in the transformation of international affairs increased greatly, and this fact challenged the static concept of the international system and, accordingly, the state's position. He posited that Turkey should move the potential of its own dynamism into the melting pot of international dynamism in order to enforce its power parameters (Davutoğlu, 2001: 10-11). To build a theoretical guide for managing this task, Davutoğlu also touched upon the changes in the global environment whereby nongovernmental agents increase their role in national strategies due to global-scaled interdependency and regional integration processes. Because the emerging MNCs, NGOs and international institutions among others have decreased the state's control in national independent economy, the states now have to harmonize their locally scaled micro strategies with macro-strategies reaching the global scale in regard to the relationship among these actors (Davutoğlu, 2001: 25). Davutoğlu also indicated the area where Turkey should focus principally as the 'near land basin' including the Balkans, the Middle East and the Caucasus. According to his doctrine, Turkey should concern itself with the cultural and political parameters and the relations of interdependency in this area in order to build an internationally substantial position there (Davutoğlu, 2001: 118).

In the Middle Eastern politics, Davutoğlu criticized the previous approach that drew on alliance politics which sought to balance the problematic neighbors with other states. For him, if Turkey continued to have crises with its neighbors it would never be able to improve regional or global strategies. The current Foreign Minister has suggested that there is no alternative alliance strategy that would overcome the costs of damages brought by constant conflicts with Iraq, Iran and Syria. He has further argued that the third parties in the alliances, such as Israel and Greece (in the case of the crisis with Syria), tend to exploit the crisis in order to increase the dependency of the conflicting sides on their own strategies (Davutoğlu, 2001: 451). Instead, Davutoğlu suggested that to overcome the tensions with its neighbors Turkey should expand the ground for relationships to economic and cultural levels that intensify societal interactions, going beyond the difficult and thorny processes between bureaucrats and politicians. For Davutoğlu, Turkey should lead the efforts in regional security and cooperation, while trying to enforce the relations of cultural-economic interdependency, specifically in the fields where Turkey feels relatively stronger (2001: 144-145).

Therefore, regarding the relations with Syria, Davutoğlu portrayed the offers such as "covering all the border with electronic security apparatuses" as irrational. Rather; he recommended economic and cultural mechanisms of cooperation like the projects to facilitate transportation, border trade, labor 
and capital flow that tend to decrease the political tensions based on the political elite's perceptions in the Middle Eastern autocratic states. For example, Davutoğlu (2001: 145-146) proposed that integrating the Halep-centered Northern Syrian economy into the booming industry in Gaziantep and Kahramanmaraş would seem to be a rational way towards building a sustainable partnership with Syria.

In foreign policy implementation, the AKP government took important steps towards realizing these objectives. In 2004, during Prime Minister Erdoğan's visit to Damascus, Turkey signed a free trade agreement with Syria to remove custom taxations and quotas gradually (Özer, 2007: 25). From then on, trade relations between the two states increased dramatically. Between 2000 and 2008, the bilateral trade volume grew from $\$ 0.72$ billion to $\$ 1.8$ billion (Tür, 2010). Turkey also encouraged its entrepreneurs to invest directly in Syria. Between 2005 and 2007 alone, Syrian authorities have approved more than thirty Turkish investment projects in the country, with a total value of over $\$ 150$ million (Gordon and Taşpınar, 2008: 58). In addition to that, the Turkish-Syrian Business Council was established that aimed at exploring the possibilities of expanding economic relations between the two countries, and entrepreneurs from both sides have begun to meet in the joint Turkey-Syria Economic Forum since 2008 (Altunışık, 2010: 152). In this sense, the energy sector became an essential area of cooperation as the two countries have established a joint company for oil exploration, and the Turkish Petroleum International Company (TPIC) began importing and exporting various oil products along with crude oil since 2008 (Ar1 and Prinççi, 2010: 10). In the new period, non-governmental actors and business associations played a crucial role in developing partnership between Turkey and Syria such as the Turkish Foreign Economic Relations Board (DEIK), the Independent Industrialists and Businessmen's Association (MUSIAD), the Turkish Exporters Assembly (TIM) and the Turkish Industrialists' and Businessmen's Association (TUSIAD). They lobbied the Turkish government, and their economic interests in the neighbor states like Syria shaped Turkey's approach to the foreign policy questions (Kirişci et al., 2010: 11).

In September 2009, two other important steps, the lifting of visa requirements and the decision to form a High Level Strategic Cooperation Council (HLSCC), were taken towards further economic integration and cooperation between the two states. Regarding lifting the visas, Turkish Foreign Minister Davutoğlu said that "we are lifting the borders which were artificially put and becoming the people of one hinterland. We are turning the economic cooperation to an economic unity. We are hoping that this will be a model for all our neighbors" (Davutoğlu, in Tür, 2010: 173). The formation of the HLSCC, on the other hand, provided a concrete mechanism that sought further cooperation in many areas. The Council decided to meet at least once a year with its high level members as the Prime Ministers and other important government officials. In addition to that, within the mechanism the ministers responsible for Foreign Affairs, Energy, Trade, Public Works, Defense, Interior Affairs and Transportation from both sides have been scheduled to meet at least twice every year with the aim at building common action plans (Tür, 2010: 174). In the first meeting of the cabinet members (September 13, 2009), it was decided to work on 40 protocols and agreements in the political, economic and social realm. In the second meeting of the Council in December 2010, another 11 agreements were signed and both sides agreed on many documents about cooperation in a wide range of areas such as social service, production and distribution of electric energy, housing, child welfare, protection of the environment and insurance policies (Coşkun, 2011). Therefore the HLSCC has served as a mechanism for both sides to manipulate economic and social structural changes in the other country. Maybe more importantly, the HLSCC and other institutional arrangements that regulate and facilitate the 
cooperation among the non-state actors and entrepreneurs from both sides (e.g. free trade agreement, joint business council and economic forum) have worked to change the very structure of TurkishSyrian relations. After putting the new face of foreign policy into force, Turkey introduced many new opportunities and extended the range of choices open to Syria that favored a cooperation vs. a conflictridden relationship as being in Strange's (1994: 31) idea of exercising structural power. Those steps towards cooperation also gave Turkey the power to shape and redirect the ties of interdependency, along with the activities of a wider range of non-state economic actors. Furthermore, Turkey's new foreign policy enhanced its soft power capability since the state began to be perceived as a benign regional power in the Middle Eastern states.

All these developments were accompanied by increasing security cooperation between Ankara and Damascus. In April 2009, Turkey and Syria concluded a technical military cooperation agreement to provide collaboration between the national defense industries. Furthermore, the first joint military exercise in the history of two sides was staged on April 27, 2009 (Arı and Prinççi, 2010: 11). It was also interesting to see that desecuritization of the Hatay issue and the water dispute became gradually evident within this rapprochement period in accordance with Davutoğlu's prospects in his Strategic Depth doctrine. As Fuller suggested, in Erdoğan's visit to Damascus in 2004, the two sides announced that there was no border problem between the two (Fuller, 2008: 180). On the other hand, the free trade agreement signed in Damascus also included provisions for mutual recognition of the borderlines (Hürriyet, 2005). However, for the eventual resolution of the problem, Assad stressed that they would need time to explain this to the Syrian people. From then on, the issue was dropped from the official lexicon, although the Hatay continued to be shown as a part of Syria on many Syrian maps (Altunişık, 2010: 153). The water dispute has also been de-linked from the security and sovereignty matters and turned into more of a technical issue that has to be dealt with through cooperation and political dialogue. In 2004, Turkey agreed to ensure the flow of more water from the Euphrates into Syria. What is more interesting to note is that the two states agreed on building a joint dam at the TurkishSyrian border over the Asi (Orontes) River in the December 2009 meeting of the HLSCC (Mağden, 2011). The foundation of that "Asi Friendship Dam" was laid in February 6, 2011. In this ceremony, Erdoğan indicated other targets for furthering cooperation with Syria such as establishing a common bank, building a common custom border gate in Nusaybin and connecting networks of natural gas distribution between Turkey and Syria (Star, 2011).

Regarding all these efforts in Turkey's new approach, it can be obviously argued that since 2004 Turkey has changed from dealing with its neighbor in the traditional sense, and instead has sought a strategic cooperation through restructuring the ground for economic and social relationships between the two sides. In fact, Turkey's new foreign policy, guided conspicuously by the Strategic Depth doctrine, resonates with the structural foreign policy's approach to the core concepts of the FPA (Keukeleire and MacNaughtan, 2008). First of all, it deals with a wide range of governmental (e.g. ministries of finance and interior) and non-governmental actors like business chambers and societies. Turkey's new approach also takes into account the other side's interest and calls for a desecuritization of the main problems. Furthermore, while Turkey has drawn on structural and soft power in its relations with Syria in the recent years, Ankara's policy has become 'context-' and 'structure-' oriented in line with the idea of a structural foreign policy, contrary to the strategy in 1990s that was driven by 'events' and 'crises.' Observing these changes, one can also argue that Turkey's regional policy now aims at restructuring the whole Middle Eastern neighborhood into a liberal-peaceful zone. Turkey's changing foreign policy approach has already expanded towards its other neighbors. Ankara has also concluded agreements 
with Iraq, Lebanon and Jordan to establish HLSCCs with them. However, designating Turkey's policy as a comprehensive structural foreign policy may still be interpreted as an overstated argument that is likely to attract academic criticism because the concept was created by Keukeleire and MacNaughtan regarding the EU's foreign policy making. The EU's structural foreign policy exerts influence at any level of the structures, including the legal systems and the public administration besides the economic and social realms through the attractiveness of a full membership status and the conditionality in the process of accession that is spelled out in certain official documents. Therefore, Turkey's structural power is more limited and seems not to be as influential as the one the EU holds especially towards the states with strong membership prospects. These limits in Turkey's new approach are examined in the next section. However it can be easily argued that Turkey's new foreign policy towards Syria could embrace the spirit of Beriker-Atiyas's article (2001). In accordance with her prospects, while seeking to create new procedures in its near environment, Turkey has also embraced the instruments of complementary diplomacy and mediation.

Although this paper has focused on Turkey's cooperation with Syria that has culminated after 2004, during this period Turkey has also sought ways to improve relations with all the actors in the region. This fact has transformed Turkey into a special country in the region that could play a mediation role between Israel and the Arab world. Specifically after the Lebanese war of 2006 the need to restart the Israeli-Syrian peace talks became evident since Syria was looking to overcome the international isolation by showing the West that it could be a serious partner in the peace efforts in the region, at the same time Israel had interests in breaking the Syria-Iran-Hezbollah link (Kirişci et al., 2010: 9). Turkey was ready to initiate a mediation process to enforce its peace building vision in the region. Syria proposed indirect talks using Turkish mediation in 2007. The Israeli President Olmert accepted the offer and, in February 2008, a secret mini-conference took place in Istanbul to set the framework of the negotiations and its content. Five rounds of meetings were organized in the following period. However, four days after the last Istanbul meeting, while Ankara was waiting for message exchange from both sides and an explanation of the discussions, Israel began its Gaza offensive. (Altunışık, 2010: 159). The process was broken and the Turkish side felt betrayed. It was followed by rising tensions between Turkey and Israel. The first stage in the crisis became the Davos meeting in January 2009 in which Erdoğan clashed with the Israeli President Peres; it was followed by some other events such as the 'lower-level sofa crisis' and the Mavi Marmara incident. ${ }^{(8)}$ Facing those developments, Erdoğan called Israel the main threat to peace in the region. The Turkish-Israeli relations rapidly deteriorated. Turkey first appealed to cancel some joint military training programs with Israel, while holding its demand on an official apology for the Mavi Marmara incident. Israel's rejection of Turkish demands, on the other side, caused further breaks in political, diplomatic and military relations between the two states, as Ankara imposed certain sanctions on Israel in September 2011 (BBC, 2011). In this sense it can be argued that Turkey's active stance in the regional politics somehow led to problems with Israel who preferred to maintain its relations with Ankara in line with the former traditional logic of alignment. And this fact enforces the observation that the regional conflicts feeding realist parameters represent formidable obstacles for Turkey's new peace building approach through regional cooperation.

\section{THE LIMITS OF TURKEY’S NEW 'STRUCTURAL’ APPROACH}

As observed above, the persistence of chronic conflicts in the Middle East seems to be the most important obstacle to Turkey's expanding its new approach to the region-wide scale. The Middle East is maybe the most fragmented region in the world as it includes the controversial axes such as Arabs 
vs. Israel, Iran vs. the Gulf States and Shiites vs. Sunnis. Ahmet Davutoğlu himself has suggested that it is the geo-politic, geo-cultural and geo-economic fragmentations that spark alliance politics regarding the balances of power and accordingly push Turkey to a periphery role (Davutoğlu, 2001: 450-451). There are always worst-case scenarios such as the possibility that the instability in Lebanon may again increase, that Israel could sharpen its policy against Syria and that the US might seek extraordinary measures against Iran's nuclear program. On the other hand, there are many global and regional powers involved in the geo-political struggle in the region, and the Middle Eastern autocratic regimes tend to look for external allies who could support them to balance internal threats by domestic opposition groups (David, 1991). ${ }^{(9)}$ As a result the picture in the Middle East is more complicated than that of the Balkans where Russian influence declined as the regional states turned to accession processes in the EU. In the Middle East, it is questionable yet whether Turkey has the means and prestige to hold the states together within its regional vision if there would be further fragmentation.

Regarding the developments in Syria since the "Arab Spring," the autocratic character of the Middle East regimes and their low level legality in the public opinion can be taken as a second impediment against the successful implementation of Turkey's new foreign policy vision. In fact, Turkey has long been recognizing the fact that those undemocratic state structures can not be maintained in the long term. That is why the Turkish President Abdullah Gül called on the Arab world to take the reins in implementing necessary political and economic reforms in 2004 and warned that if the leaders in the Middle East do ignore domestic problems, other foreign powers will try to solve them in their own way and interfere in those countries' domestic affairs (Gül, in Murinson, 2006: 953). As noted above, since 2004 the Turkish side has also induced Damascus to make the necessary domestic reforms. Even after the domestic unrest broke out in March 2011, Turkey has maintained its long preference for close contacts with the Assad regime, in the hope that the latter would take into consideration Ankara's advice for democratization reforms (e.g. lifting of emergency rule and permitting foundation of multi-parties) and would manage the process successfully. Turkey has favored a prudent and healthy transformation towards democracy in the state, rather than a violent revolution or a civil war that would negatively influence the bilateral political and economic cooperation and integration that, to some extent, had been achieved in the first decade of the 2000s. However the Syrian government's reform efforts appeared only in rhetoric, while the Assad regime continued to confront the civil opposition using heavy arms through the year of 2011. The events have led to hundreds of casualties (see $N Y$ Times, 2011). After Davutoğlu's visit to Damascus in August which failed to provide the expected results, Turkey has seemed to lose hope in the current Syrian government. ${ }^{(10)}$ Thus cold winds again blow between the two states.

In this context, one can conclude that the material benefits brought by the new Turkish foreign policy which restructured economic and social dimensions of bilateral relations did attract Damascus, yet Ankara's other inclusive objective of creating a sustainable and stable political structure in Syria by and large failed because the Syrian government considered that the change in political structure would undermine the regime's power and lead to its fall. At this point, the deterioration of Turkish-Syrian relations again in 2011 confirms Keukeleire and MacNaughtan's (2010) suggestion that a successful structural foreign policy needs to focus on all relevant structures (e.g. political, legal, and economic structures) together. Otherwise, the authors argue, "neglecting one or more relevant levels or sectors can undermine the achievements at other levels and structures" (Keukeleire and MacNaughtan, 2010: 5). Turkey's structural power, in this sense, faces huge challenges when dealing with the decades-old autocratic political traditions. Ultimately the current political tensions between Ankara and Damascus 
may well push Turkey into turning to some coercive methods (i.e. arms embargo and economic measures) again in its foreign policy implementation. ${ }^{(11)}$

In the aftermath of the Arab revolts, Turkey's and the Western powers' approaches towards the Arab world, along with the internal dynamics in those states, will be determining factors in shaping the future political structures in this region. It is even clear that economic restructuring will remain at the top of the agendas of outside powers. But still, the Western powers' structural power capacity to contribute a healthy transformation towards democracy in those states will be limited if they continue to shape their regional policies based on the security paradigms. For long years, even the EU, the leading actor in manipulating democratic transformation in its periphery, has adopted the securitization perspective towards the region. The EU has supported the autocratic leaders in those states as long as they cooperated against illegal migration, fundamentalist and terrorist movements and provided trade liberalization (Kutlay and Dinçer, 2011). Following the Arab uprisings, the EU as well as the US should now adopt a more comprehensive foreign policy that focuses on the political structures themselves for fostering long-standing stability in the region, rather than pursuing their short-term security needs. On the other hand, many analysts argue that Turkey's increasing soft power capacity in the recent years now enables Ankara to guide the transformation processes in the Arab world by sharing the Turkish historical experiences of democratization with those states. This might spark a new concept of partnership between the Western world and Turkey in the aftermath of the Arab revolts (see Kutlay and Dinçer, 2011).

Last but not least, the third limitation of Turkey's new foreign policy approach that draws on soft and structural power seems to be the dependence of its attractiveness in its Western vocation. Back in 2004, Turkey's institutionalized relations with the Western world became the main factor that attracted Damascus and induced its orientation towards Ankara when it was facing a campaign of political isolation (Tür, 2010: 169-171). Also today, the rising sympathy towards Turkey in the Arab countries has partly been fed by the belief that Ankara would stand for their rights and legitimate interests in the international organizations and platforms. In addition to that, some scholars have suggested that the foreign policy change became possible through the Europeanization process that led to domestic reform in the civilian-military balance and eliminated 'hard power' as an instrument in dealing with the neighbors (Aras and Polat, 2008; Aydın and Açıkmeşe, 2007). Accordingly it means that Turkey should give considerable importance to its relations with the EU, while encouraging a liberalization process in its neighborhood.

Still, the disappointment in the EU membership prospects in Turkey since 2006, and Ankara's increasing partnership with its neighbors has fed the anxiety in the Western world about a shift in the axis. It was coupled with the crisis in Turkish-Israeli relations and Turkey's moves to seek a balance between Iran and the Western states in dealing with the nuclear problem (see Çandar, 2009). Under these conditions, some even argued that Turkey now "could opt for a more nationalistic and authoritarian path that seeks closer relations with the sometime rivals of the United States such as Russia, Iran, China, and Syria" (Gordon and Taşpınar, 2008: 4). However, this paper has exposed the content of the new approach as not a new orientation in alignment policy, but a strategy to seek a sustainable partnership with the regional states through economic integration in line with a globalization perspective that would reduce the costs of conflict-ridden relationships. The new approach of Turkey, in this sense, could sometime lead to more independent behaviors that give privilege to developing interest with the neighbors as in the case of its relations with Syria in 2004. Although it would contrast with the prospects of those 
who used to observe Turkey's close alignment strategy with the West in a traditional realist sense, here it is argued that Turkey's constructive approach would serve for peace building and liberalization efforts in the region. Nonetheless, if Turkey could manage to avoid tensions with Israel and to enforce the partnership with the EU, these would only positively influence the successful implementation of Turkey's regional peace building vision.

\section{CONCLUSION}

This paper has examined Turkish foreign policy change towards Syria in a globalization perspective. Although the challenges of globalization to traditional foreign policy making became influential in shaping the new approach by Turkey, the other reasons that facilitated the foreign policy change, such as the shifting regional dynamics, are underlined. At first, it may seem that the neorealist perspective that focuses on the balance of power and the distribution of threats could explain the foreign policy change. But the literature on neorealism remains limited in covering significant aspects of our subject due to its sole concentration on power politics. Therefore, examining the changing nature of TurkishSyrian relations covering the economic and social realms required a reference to some theoretical approaches on globalization's challenge to traditional foreign policy formation. In this respect, the AKP's foreign policy making covers many significant elements based on an understanding of the new conditions in the globalization process. Turkey did not content itself with security cooperation with Syria after 1998, but sought an enforced partnership with its neighbor that was based on a relationship of interdependency. That promoted many new opportunities for collaboration among the wider range of economic and political actors from both sides which favored cooperation vs. conflict. Unfortunately, the Turkish-Syrian relations deteriorated again in the face of the domestic crisis in Syria in 2011. However, Turkey's recent experiences of restructuring economic and social processes in its neighborhood will likely facilitate Ankara's other foreign policy maneuvers towards the Middle East in the future. It is also not to be forgotten that the foreign policy change seems to increase Turkey's soft power capacity in the Middle East because the new Turkish foreign policy vision has been generally welcomed by the Arab word. This fact would introduce many opportunities for Turkey to influence the political, economic and social transformation processes in the Middle East in the aftermath of the "Arab Spring."

\section{NOTES}

1. Even though Joseph Nye, one of the most prominent contributors to soft power concept, admits that some goals can only be achieved by hard power, he appreciates combining both notions of power (hard and soft) together within the concept of 'smart power' (2004).

2. As noted, this paper is based on an earlier draft of a conference paper presented in April 2011. During its preparation, the spillover effects of the Arab revolts into Syria was solely limited to lower scale events in Daraa town, therefore, the implications of the revolts in the country did not make for a special accounting in the plan of the study that focused on the comparative examination of Turkish changing foreign policy. However, through some later work, the developments related to the Arab uprisings were incorporated in the study to the extent they generated implications for our subject, Turkish foreign policy change towards Syria in the last several years. Those implications are mostly discussed in the last section, namely "the limits of Turkey's new 'structural' approach." 
3. Balance-of-threat theory defines alliances as a response to external threat. In this theoretical logic, states facing a threatening power mostly prefer balancing that power with available allies who share common threat perceptions (Walt, 1987). In the 1990s, Turkey faced an imminent threat from Syria appearing as an explicit support of the PKK. Because Ankara had problems with the US and the European powers who had raised their criticism on human right concerns in Turkey's struggle against the PKK, Israel emerged as the most available ally for Turkey. In this context, Israel also served as a military source for the modernization of the Turkish army in a period when the US was not willing to sell weaponry due to the Greek and Armenian lobbying. (Martin, 2004: 184).

4. It is, in fact, a disputed question over why Turkey waited so long until October 1998 to play the card of a military threat (see Aykan, 1999: 179 and Sezgin, 2002).

5. When Sezer's visit came to the agenda, Washington declared that "the European states and Egypt were agreed on the implementation of sanctions against Syria, and Turkey was expected to support the decisions of the international community" (Ayhan, 2009: 30).

6. At that point in time, it seemed equally possible that the two states would engage in some formal or informal arrangements of security cooperation in the balance-of-threat perspective since the distribution of threats in the region changed as well as the threat perceptions of both sides that were now converged (Walt, 1987). In neorealism, in general, alliances are also defined as temporary and they tend to be reshaped when the units realize that realignment would serve to benefit of balances of power (Sheehan, 1996: 55-56).

7. I preferred taking the signing of the Free Trade Agreement in 2004 as the starting point of the new approach because the changes in the multiple levels of Turkish-Syrian relations mostly followed this landmark.

8. In January 2010, Israeli Deputy Foreign Minister Danny Ayalon publicly insulted the Turkish ambassador by seating him on a lower-level sofa in front of the TV cameras. Ayalon furthermore said to the cameras that "[Note] that he is sitting in a lower chair and we are in the higher ones, that there is only an Israeli flag on the table." (Kösebalaban, 2010: 38). The Mavi Marmara incident, on the other hand, refers to the Israeli navy's armed attack on the Turkish vessel Mavi Marmara that carried humanitarian aid to Gaza under Israel's blockade, on May 31, 2010.

9. According to David's omnibalancing perspective that examines alliance formation in the Third World, internal threats also serve as significant motives in the Third World leaders' alignment preferences. Because the regime legality is low and internal conflicts and military coups seem to be the most common forms of government change in those states, David suggests the Third World leaders' alignment strategies are based on the rational calculation "as to which outside power is most likely to do what is necessary to keep them in power" (David, 1991: 235). Therefore here it is suggested that the Middle Eastern autocratic regimes tend to resist the structural changes towards the liberalization sought by Turkey that would weaken their domestic position especially when they can find external allies with significant interests in maintaining their rule.

10. The Turkish PM Erdoğan himself later confirmed that he cut all contacts with the Syrian administration on September 23, 2011 (Time, 2011). 
11. According to the press, Turkey has began to impose an arms embargo towards Syria, in late September and already intercepted a Syrian-flagged ship in the Sea of Marmara that was carrying weapons to Syria. On September 20, 2011, the Anatolia news agency quoted from Erdoğan that "We have already made a decision to stop and prevent any vehicle carrying any type of weapon to Syria. We told them our decision as well as shared it with neighboring countries" (Haaretz, September 24, 2011). On the other hand, Haaretz reported from Erdoğan that Turkey might impose economic sanctions on Damascus. However Turkey has not indicated yet what type of sanctions it might impose on Syria (see Haaretz, September 24, 2011).

\section{REFERENCES}

Altunış1k, M.B. and Tür, Ö. (2006). "From Distant Neighbors to Partners? Changing Syrian-Turkish Relations," Security Dialogue, 37(2): 229-248.

Altunışık, M.B. (2010). “Turkey’s Changing Middle East Policy,” UNISCI Discussion Papers, 23: 149-162.

Aras, B. and Polat, R.K. (2008). "From Conflict to Cooperation: Desecuritization of Turkey's Relations with Syria and Iran," Security Dialogue, 39(5): 495-515.

Aras, G. and Crowther, D. (2009). "Corporate Governance and Corporate Social Responsibility in Context," in G. Aras and D. Crowther (eds.), Global Perspectives on Corporate Governance and CSR: 1-41. Farnham: MPG Books Group.

Arı, T. and Pirinççi, F. (2010). "Turkey's New Foreign Policy towards the Middle East and the Perceptions in Syria and Lebanon," Gazi Akademik Bakış Dergisi, 4(7): 1-16.

Aydın, M. (2003). "Kafkasya ve Orta Asya'yla İlişkiler (Relations with the Caucasus and the Central Asia)," in B. Oran (ed.), Türk Dış Politikası (Turkish Foreign Policy): 366-440. İstanbul: İletişim Yayınları.

Aydın, M. and Açıkmeşe, S. (2007). "Europeanization through EU Conditionality: Understanding the New Era in Turkish Foreign Policy," Journal of Southern Europe and the Balkans, 9(3): 263-274.

Ayhan, V. (2009). "Türkiye-Suriye İlişkilerinde Yeni Bir Dönem: Yüksek Düzeyli Stratejik İşbirliği Konseyi (A New Period in Turkish-Syrian Relations: High Level Strategic Cooperation Council)," Ortadoğu Analiz, 1(11): 26-34.

Aykan, M.B. (1999). "The Turkish-Syrian Crisis of October 1998: A Turkish View," Middle East Policy, 6(4): 174-191.

BBC (2011). "Turkey Suspends Israel Defence Ties over Gaza Aid Raid," September 6. Available [on line] at: http://www.bbc.co.uk/news/world-europe-14800305 (accessed 10.09.2011).

Bengio, O. and Özcan, G. (2000). “Changing Relations: Turkish - Israeli - Arab Triangle,” Perceptions, 5(1): 136-146. 
Beriker-Atiyas, N. (2001). "Yeni Dünya, Eski Yaklaşımlar (The New World, Old Approaches)," Foreign Policy (Turkish Print), 1: 46-54.

Bozdağlığlu, Y. (2003). Turkish Foreign Policy and Turkish Identity: A Constructivist Approach. New York: Routledge.

Çandar, C. (2009). “Turkey's 'Soft Power' Strategy: A New Vision for a Multi-Polar World,” SETA Policy Brief, No: 38.

Chong, A. (2007). Foreign Policy in Global Information Space: Actualizing Soft Power. New York: Palgrave Macmillan.

Coşkun, G. (2011). “Ortadoğu'da Model Ortaklık: Türkiye-Suriye İlişkileri (Model Partnership in the Middle East: Turkish-Syrian Relations)," USAK Stratejik Gündem, February, 11. Available [on line] at: http://www.usakgundem.com/yazar/1967/ortado\%C4\%9Fu\%E2\%80\%99da-modelortakl\%C4\%B1k-t\%C3\%BCrkiye-suriye-\%C4\%B0li\%C5\%9Fkileri.html (accessed 27.02.2001).

David, S.R. (1991). “Explaining Third World Alignment,” World Politics, 43(2): 233-256.

Davutoğlu, A. (2001). Stratejik Derinlik: Türkiye’nin Uluslararası Konити (Strategic Depth: Turkey’s International Position). Istanbul: Küre Yayınları.

Fuller, G.E. (2008). The New Turkish Republic: Turkey as a Pivotal State in the Muslim World. Washington: US Institute of Peace.

Garrison, J.A., Kaarbo, J., Foyle, D., Schafer, M., and Stern, E.K. (2003). "Foreign Policy Analysis in 20/20: A Symposium," International Studies Review, 5(2): 163-170.

Gordon, P.H. and Taşpınar, Ö. (2008). Winning Turkey: How America, Europe and Turkey can Revive a Fading Partnership. Washington D.C.: Brookings Inst. Press.

Groom, A.J.R. (2007). "Foreign Policy Analysis: From Little Acorn to Giant Oak?" International Studies, 44(3): 195-215.

Haaretz, (2011). “Turkey Seizes Syrian Ship, Announces Arms Embargo," September 24. Available [on line] at: http://www.haaretz.com/news/middle-east/turkey-seizes-syrian-ship-announces-armsembargo-1.386476 (accessed 25.09.2011).

Held, D., McGrew, A., Goldblatt, D., and Perraton, J. (2003). "Rethinking Globalization," in D. Held and A. McGrew (eds.), The Global Transformation Reader: An Introduction to the Globalization Debate: 67-74. Cambridge: Blackwell Publishing.

Hill, C. (2003a). The Changing Politics of Foreign Policy. London: Palgrave Macmillan.

------, (2003b). "What Is to Be Done? Foreign Policy as a Site for Political Action," International Affairs (Royal Institute of International Affairs 1944-), 79(2): 233-255. 
Holden, P. (2009). In Search of Structural Power: EU Aid Policy as a Global Political Instrument. Farnham: Ashgate.

Hürriyet, (2005). "Hatay’a Gizli Çözüm (Secret Solution for Hatay),” January 10. Available [on line] at: http://hurarsiv.hurriyet.com.tr/goster/haber.aspx?viewid=521676 (accessed 01.03.2011).

James, C.C. and Özdamar, Ö. (2009). "Modeling Foreign Policy and Ethnic Conflict: Turkey’s Policies Towards Syria," Foreign Policy Analysis, 5: 17-36.

Jung, D. (2005). "Turkey and the Arab World: Historical Narratives and New Political Realities," Mediterranean Politics, 10(1): 1-17.

Keukeleire, S. (2002). "Reconceptualizing (European) Foreign Policy: Structural Foreign Policy." Paper presented at the 1st Pan-European Conference on European Union Politics, Bordeaux, (September).

Keukeleire, S. and MacNaughtan, J. (2008). The Foreign Policy of the European Union. Houndmills: Palgrave Macmillan.

-----, (2010). "Structural Diplomacy, Contextual Difference, and the Process of Learning." Paper presented at the UACES 40th Anniversary Conference, Bruges, Belgium, (September).

Kirişci, K., Tocci, N., and Walker, J. (2010). “A Neighbourhood Rediscovered: Turkey's Transatlantic Value in the Middle East," Brussels Forum Paper Series. Washington DC: German Marshall Fund of the United States, (March).

Kösebalaban, H. (2010). "The Crisis in Turkish-Israeli Relations: What is Its Strategic Significance?” Middle East Policy, 16(3): 36-50.

Kutlay, M. and Dinçer, O.B. (2011). “Arap Baharı, Türkiye-AB İlişkilerini Yeniden Ateşler mi? (Would the Arab Spring Spark Turkish-EU Relations Again?),” Analist, 6: 12-23.

Laçiner, S. (2009). “Turgut Özal Period in Turkish Foreign Policy: Özalism.” Turkish Weekly. Available [on line] at: http://www.turkishweekly.net/article/333/turgut-\%C3\%B6zal-period-inturkish-foreign-policy-\%C3\%B6zalism.html (accessed 10.02.2010).

Mağden, T.E. (2011). “Ortadoğu İçin Örnek Bir İşbirliği: Türkiye-Suriye Asi Nehri Dostluk Baraj1 (An Exemplary Cooperation for the Middle East: Turkey-Syria Asi (Orontes) River Friendship Dam)," ORSAM Dış Politika Analizi, February, 7. Available [on line] at: http://www.orsam.org.tr/tr/yazigoster.aspx?ID=1488 (accessed 01.03.2011).

Martin, L.G. (2004). “Turkey's Middle East Foreign Policy,” in L.G. Martin and D. Keridis (eds.), The Future of Turkish Foreign Policy: 157-191. Cambridge: The MIT Press.

Murinson, A. (2006). "The Strategic Depth Doctrine of Turkish Foreign Policy," Middle Eastern Studies, 42(6): 945-964. 
Nye, S.J. (2004). “Soft Power and American Foreign Policy,” Political Science Quarterly, 119(2): 255-270.

NY Times, (2011). "Syria — Protests (2011)," September 20 (last update). Available [on line] at: http://topics.nytimes.com/top/news/international/countriesandterritories/syria/index.html (accessed 23.09.2011).

Orhan, O. (2009). “ABD-Suriye İlişkilerinde Değişim ve Türkiye’nin Ortadoğu'daki Rolü (Change in USA-Syria Relations and Turkey's Role in the Middle East)," ORSAM Gündem Analiz, 3: 1-11.

Özer, D. (2007). "Syria and Turkey Relations: The Changing Face of Turkish Foreign Policy," Civilacademy: Journal of Social of Sciences, 5(3): 15-29.

Pamukçu, K. (2004). "Su Sorunu Çerçevesinde Türkiye, Suriye ve Irak İlişkileri (Turkish Syrian and Iraqi Relations within the Framework of the Water Problem)," in F. Sönmezoğlu (ed.), Türk Dış Politikasının Analizi (The Analysis of Turkish Foreign Policy): 253-270. Istanbul: Der Yayınları.

Sezgin, Y. (2002). "The October 1998 Crisis in Turkish-Syrian Relations: A Prospect Theory Approach," Turkish Studies, 3(2): 44-68.

Sheehan, M. (1996). Balance of Power: History and Theory. London: Routledge.

Star, (2011). "Başbakan Erdoğan Asi Dostluk Barajı Temel Atma Töreninde Konuştu (Prime Minister Erdoğan Addressed at the Groundbreaking Ceremony of the Asi (Orontes) Friendship Dam)," February, 6. Available [on line] at: http://www.stargazete.com/politika/serde-degil-hayirda-yarisalimhaber-328765.htm (accessed 01.03.2011).

Strange, S. (1994). States and Markets. 2nd ed. London: Pinter.

Time, (2011). “Turkey Slaps Arms Embargo on Syria," September 24. Available [on line] at: http://www.time.com/time/world/article/0,8599,2094763,00.html (accessed 24.09.2011).

Tür, Ö. (2010). “Turkish-Syrian Relationship -- Where Are We Going”, UNISCI Discussion Papers, 23: $163-176$.

Walker, J. (2006). "Turkey and Israel's Relationship in the Middle East," Mediterranean Quarterly, 17(4): 60-90.

Walt, S.M. (1987). The Origins of Alliances. New York: Cornell University Press. 